\title{
DARK STATES OF SYMMETRIC POLYMETHINE DYES REVEALED BY PUMP-DUMP-PROBE SPECTROSCOPY
}

\author{
K. Redeckas ${ }^{a}$, V. Voiciuk ${ }^{a}$, A.A. Ishchenko ${ }^{b}$, and M. Vengris ${ }^{a}$ \\ ${ }^{a}$ Laser Research Center, Faculty of Physics, Vilnius University, Sauletekio 10, 10223 Vilnius, Lithuania \\ ${ }^{\mathrm{b}}$ Institute of Organic Chemistry, National Academy of Sciences of Ukraine, Murmanska St. 5, 02094 Kyiv, Ukraine \\ Email: mikas.vengris@ff.vu.lt
}

Received 7 December 2018; accepted 2 January 2019

\begin{abstract}
We have applied three-pulse transient absorption spectroscopy to investigate the ultrafast photoisomerization dynamics in two symmetric polymethine dyes. Pump-deplete-probe experiments have revealed that the excited state manifold of these molecules contains two closely lying excited states in the dynamic equilibrium. One of these states is emissive, while the other is largely dark. It is the dark state that ultimately results in the photoisomer formation and is the main channel of excited state decay in these dyes. We have shown that excited state populations do flow between these two states and therefore it can be inferred that the photoisomerization pathway is not predetermined by ground state distortions of the molecular structure. The decision whether the molecule will isomerize or not seems to be taken in the excited state. Global analysis of three-pulse transient data allowed us to determine the spectra of the excited and ground intermediate states and build a comprehensive picture of photoinduced dynamics in symmetric polymethine dyes.
\end{abstract}

Keywords: three-pulse transient absorption spectroscopy, polymethine dyes

PACS: 82.53.Uv

\section{Introduction}

Since their discovery more than a century ago, cyanines (polymethine dyes) have found widespread applications due to the easy tunability of their spectral properties. The straightforward variation of their chemical structure by adding conjugated double bonds in the polymethine bridge allows tuning the absorption and fluorescence bands of the dye from UV to IR. Numerous polymethine compounds have been synthesized and extensively studied [1, 2]. In recent years, polymethine dyes are widely used for biomedical imaging [3-7], such as the selective marking of different sub-cellular components [8-12], Förster resonance energy transfer microscopy [13-15] and fluorescence lifetime imaging [16, 17]. Therefore, the excited state dynamics of dye compounds and the structure-function relationship remain the object of current scientific research [18-20]. Cyanine dyes have also attracted the interest of researchers due to their ability to form J-aggregates. In fact, the J-aggregates were first discovered in aqueous solutions of pseudoisocyanine (PIC) [21, 22]. On the other hand, monomeric forms of cyanine dyes are actively investigated as well. Photoisomerization of cyanines was first observed in column chromatography experiments in 1953 [23]. The earliest extensive reports on the transient absorption of several polymethine dyes [24-27] proposed the formation of photoisomers in the excited state relaxation pathway. Photoisomerization of $\mathrm{C}=\mathrm{C}$ bonds is one of the main reactions in photochemistry, extensively studied by time-resolved spectroscopy [28-33]. Trans-cis photoisomerization is a change of the dihedral angle between different parts of the molecule around the double bond in the excited state, followed by 
the relaxation to the ground state with a changed conformation. The latter subsequently reverts back to the initial form via thermal activation. Such model of photoisomerization was first proposed for stilbene [34] and later extended to polymethine dyes [35-37]. All-trans isomers (usually considered the most stable ground state conformation of polymethine dyes) are excited vertically to the first excited state, which further relaxes via two competitive channels: fluorescence and rotation around the double bond. On the $\mathrm{S}_{1}$ potential surface, the all-trans and $90^{\circ}$ conformations are separated by an energy barrier of less than few tens of $\mathrm{kJ} / \mathrm{mol}$ [38]. The molecule quickly overcomes the barrier and reaches the potential minimum of the $90^{\circ}$ conformation. Twisted excited molecules non-radiatively relax to either the trans or the cis ground state conformation. Finally, cis isomers thermally revert to the initial trans form, which is the favoured direction of the ground state isomerization in cyanine dyes [25]. Alternatively, it has been suggested that in some cases moderately stable twisted species can exist in the ground state, corresponding to an extra shallow energy minimum on the $S_{0}$ surface [37, 38]. The absorption spectra of cyanine cis or twisted isomers strongly overlap with those of trans isomers and usually are bathochromically shifted [39]. The existence of twisted species may explain unusually short lifetimes of cyanine photoisomers. The detailed pathway of photoisomerization reaction depends on the shape of excited and ground state potential energy surfaces. The rate of thermal conversion depends on the friction between the rotating group and solvent molecules, therefore the shape and size of the rotating group and the nature of the solvent are rate-determining factors [24, 40]. Obviously, the two proposed physical pictures are different: in the first scenario the excited molecules undergo two different twisting pathways, whereas in the second scenario several sub-populations preexist in the ground state and follow their respective dynamics independently.

In a recent paper, we have reported the ultrafast dynamics of a series of polymethine dyes, where we observed short and long-lived ground state isomers, depending on the specific dye structure [41]. As with other molecules of this class, the precise pathway of isomer formation could not be established unambiguously from pump signals alone. Here we addressed this question using the ultrafast pump-dump-probe (PDP) spectroscopic technique that allows disentangling complex dynamic processes that remain obscure in conventional pump-probe measurements [4245]. The combination of three-pulse experiments with the the global analysis of spectrotemporal data allowed us to unravel optically dark states that could not be observed directly using the conventional pump-probe spectroscopy.

\section{Materials and methods}

Figure 1 shows the structural formulae of investigated compounds, along with their steady-state absorption and fluorescence spectra. The synthesis of the compounds has been reported previously in Refs. [46, 47]. From a larger class of available dyes, we chose two molecules with the shortest polymethine bridges, where the transient ground state species was clearly observed in the pumpprobe spectra [41]. Crystalline samples were dissolved in acetone (Sigma-Aldrich, gradient grade). Solution concentrations were adjusted to yield ca. $0.8-1 \mathrm{OD}$ at the excitation wavelength in a $1 \mathrm{~mm}$ optical path fused silica cell. Steady-state absorption and fluorescence spectra were measured using a Shimadzu UVPC-3100 spectrophotometer and a Perkin-Elmer Lambda LS-55 fluorimeter, respectively. The experimental setup for multi-pulse transient absorption experiments was described in detail in Ref. [48]. The samples were excited at $550 \mathrm{~nm}$ (a green spectrum in Fig. 1) using $50 \mathrm{~nJ}$ excitation pulse energy, and dumped using $650 \mathrm{~nm}$ pulse (a brown spectrum in Fig. 1) and $500 \mathrm{~nJ}$ energy. The polarizations of pump and dump pulses were parallel to each other and at a magic angle $\left(54.7^{\circ}\right)$ with the probe pulse polarization.

\section{Results}

As evident from Fig. 1, the dump pulse is timed to arrive at the instance when the excited state has had some time to equilibrate, but has not relaxed yet, and a significant stimulated emission (SE) contribution is observed in the pump-probe signal (negative bands at wavelengths larger than $580 \mathrm{~nm}$ ). The wavelength of the dump pulse was set to interact exclusively with a red wing of the SE band in both molecules. This pulse depletes the excited 

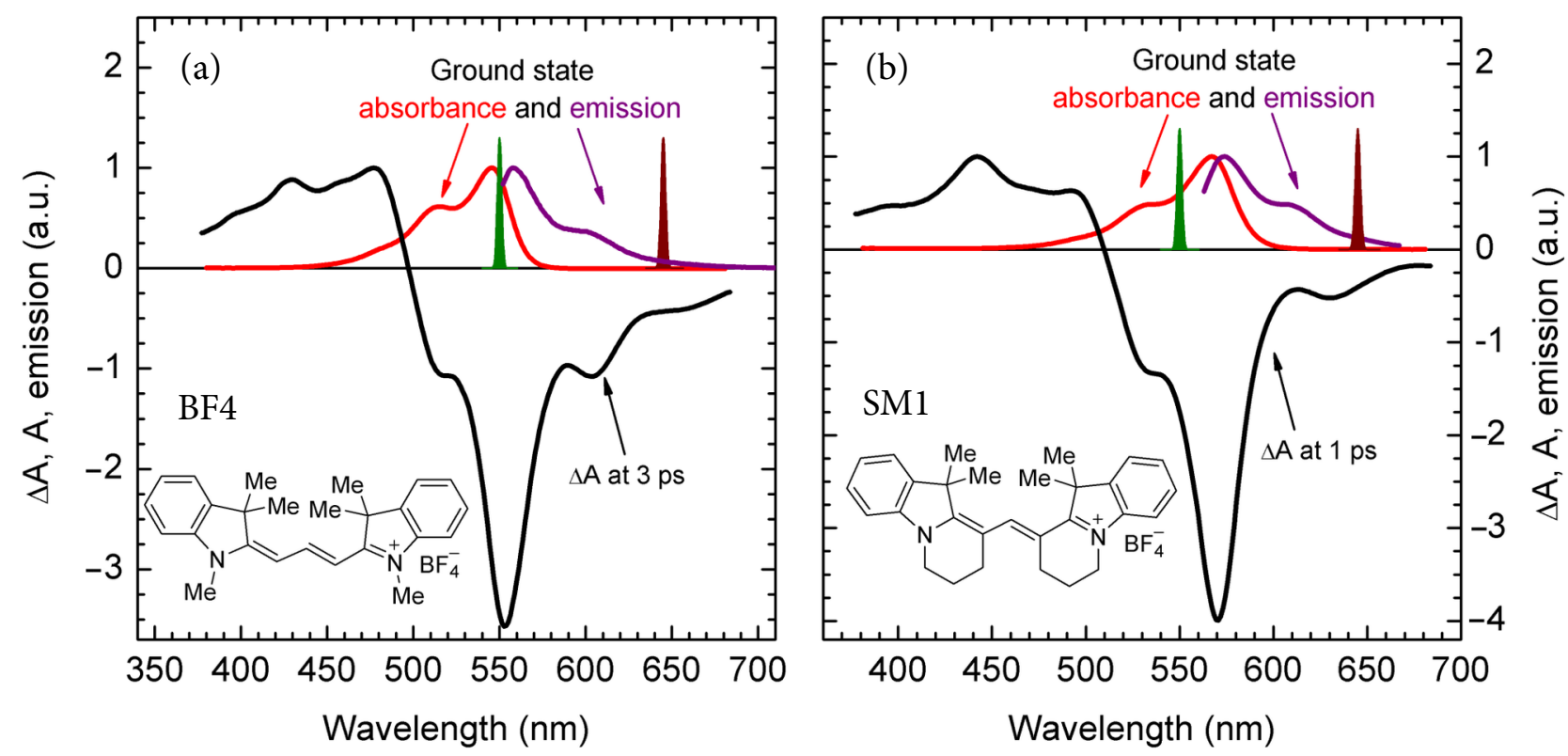

Fig. 1. Structural formulae, absorption (red online) and emission (purple online) spectra of two investigated polymethine compounds. The spectra of pump and dump laser pulses are shown in green and brown (online), respectively. Superimposed on the steady state spectra is the difference absorption (black lines) measured at the instance of dump pulse arrival ( 3 ps in BF4 and 1 ps in SM1).

state of the dye molecules and demotes them back to the ground state. As a result, any isomerization reaction that might take place is 'short-circuited'.

The representative pump-probe (PP) spectra measured on BF4 and SM1 are presented in Fig. 2. Although the timescales of the observed processes

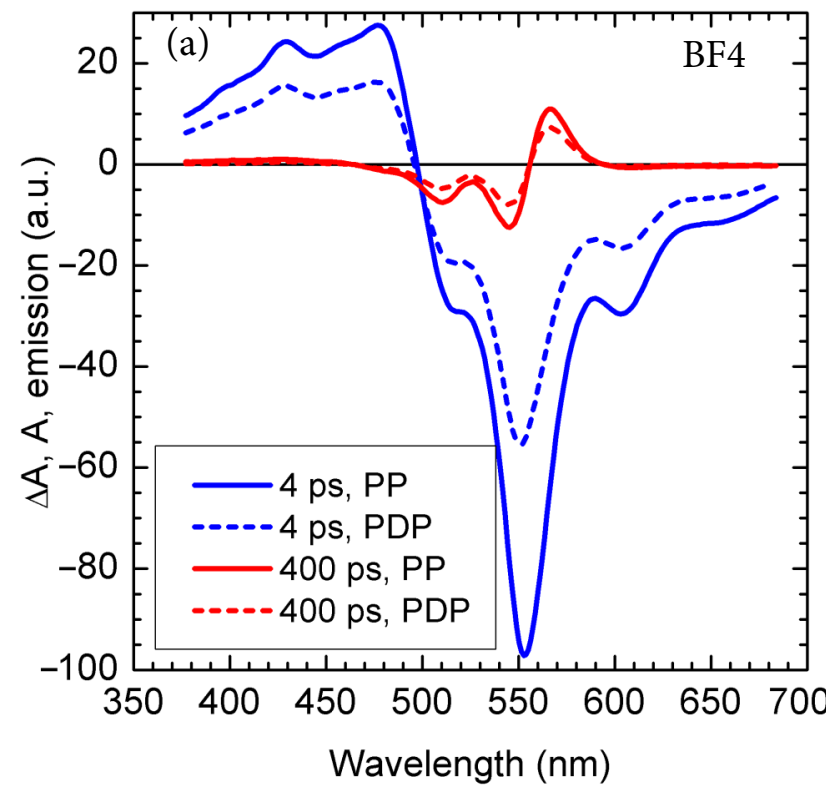

are very different, the spectral shapes of PP signals are highly similar in both dyes. At early times (see blue solid lines in Fig. 2), the transient spectra are dominated by an intense negative signal, spanning from $500 \mathrm{~nm}(\mathrm{BF} 4)$ or $520 \mathrm{~nm}(\mathrm{SM} 1)$ to $680 \mathrm{~nm}$. This is a compound signal produced by overlapping

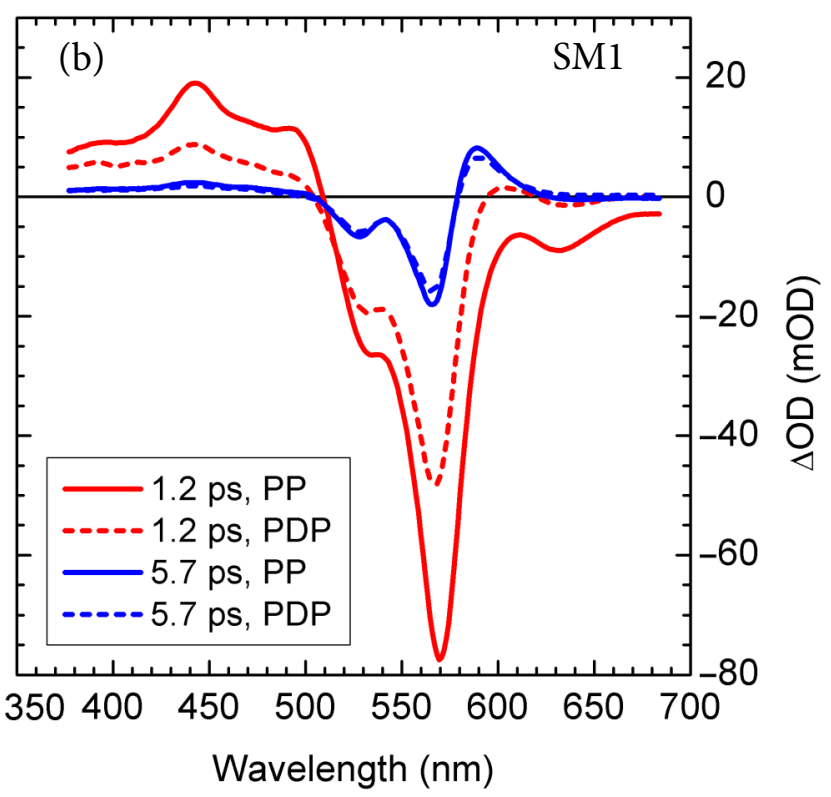

Fig. 2. (a) Transient absorption spectra in the absence (solid lines, PP) and in the presence (dashed lines, PDP) of the dump pulse measured in BF4 immediately after the dump pulse and at the time when an unrelaxed ground state intermediate is observed. The dump pulse arrived at $3 \mathrm{ps}$ after the pump pulse. The delay times, at which the spectra were measured, are given in graph legends. (b) The same data for the SM1 compound. 
ground state bleaching (GSB) and SE bands. Additionally, a broad excited state absorption (ESA) is observed to the blue from the absorption maximum.

This initial spectrum gradually decays, exposing the contribution of a new transient species (red solid lines in Fig. 2), which exhibits a positive band in the region where SE was initially observed. The newly formed spectrum has an induced absorption (IA) peak at $565 \mathrm{~nm}$ (BF4) or $585 \mathrm{~nm}$ (SM1), and a negative contribution of the GSB signal.

The arrival of the dump pulse at 3 ps in the case of BF4 and 1 ps in SM1 removes the population from the excited state, as is clearly visible from the comparison of the solid and dashed blue lines in Fig. 2. The SE signal in the dump-affected transient absorption spectrum (PDP) is diminished by $50 \%$ in the case of BF 4 and nearly $100 \%$ in the case of SM1. Interestingly, the effect of dump- ing on the later transient species is significantly smaller than on the early spectrum, indicating that the observed dynamics is more complex than a straightforward decrease in a single excited state population.

Kinetic traces measured in the PDP experiment on BF4 are presented in Fig. 3, which shows the signals probed at wavelengths with a single dominating contribution: (a) the $S_{1}$ ESA signal at $430 \mathrm{~nm}$; (b) the ground state species, reflected by GSB at $530 \mathrm{~nm}$, with minor contributions from $\mathrm{SE}$, yet with an unavoidable overlap with photoisomer spectra; (c) the largest contribution of isomer absorption and some SE at $570 \mathrm{~nm}$; (d) the SE region (wavelengths longer than $630 \mathrm{~nm}$ ). A high efficiency of the interaction between the excited molecules and the dump pulse is evidenced by significant changes in the PP signal (red traces) throughout the entire spectrum, with losses of ca. $45 \%$ observed in the 'clean' SE region. A surprising
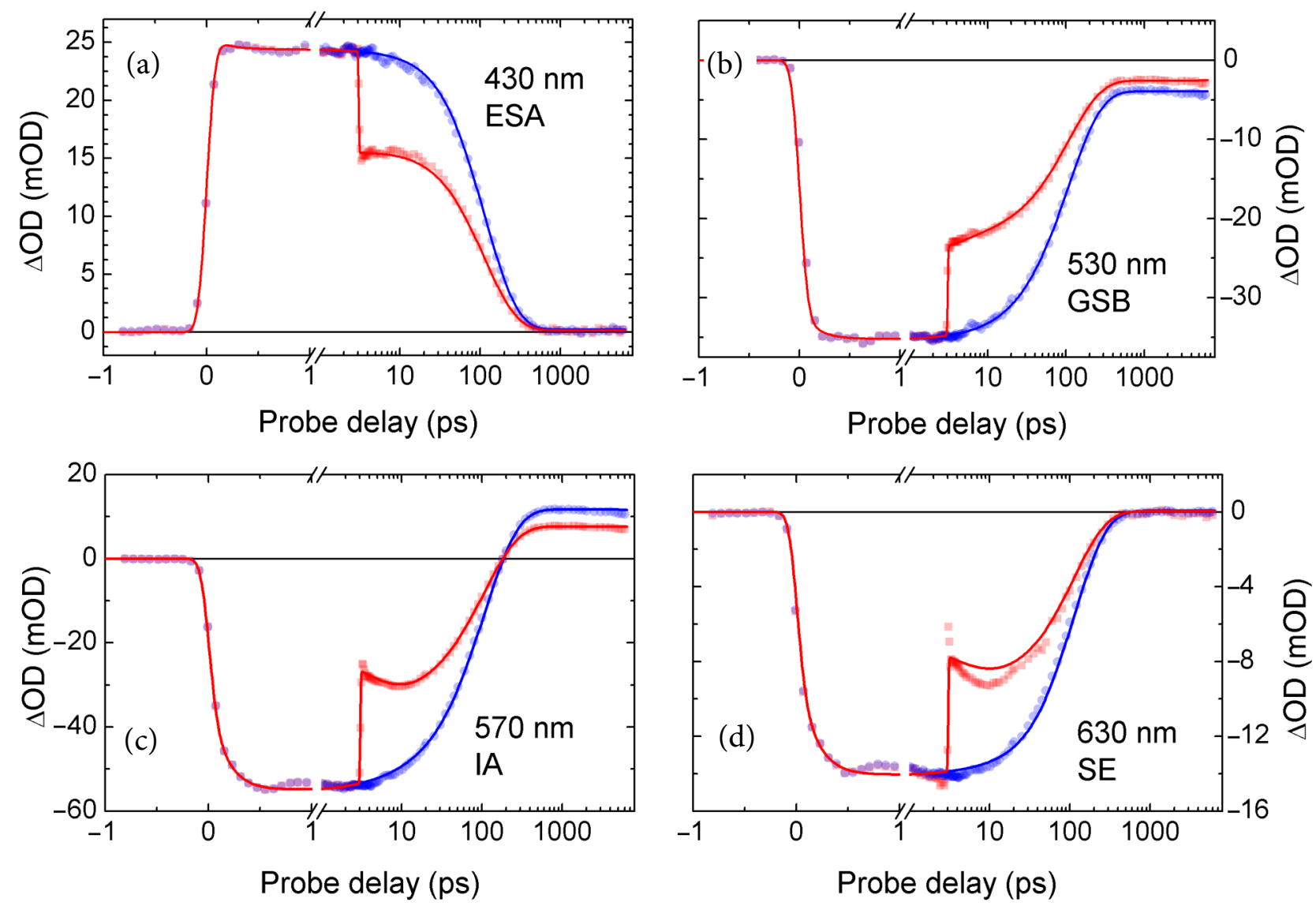

Fig. 3. PDP kinetics of BF4: PP (blue (online) circles) and PDP (red (online) squares) traces measured at different probe wavelengths with major contributions from ESA (a), GSB (b), IA of photoisomer (c) and SE (d) bands. Solid lines correspond to the global fitting results employing the connectivity scheme shown in Fig. 6. The dumping time was 3 ps. 
feature can be observed in the PDP traces at SE wavelengths (Fig. 3(d)): after an instantaneous decrease due to the dump, the SE signal exhibits a slight recovery. From the instance of the dump until about $10 \mathrm{ps}$, the dumped and undamped signals are changing in opposite directions. When the PDP signal reaches a local minimum (corresponding to a locally maximal SE), the two traces further decay in unison. Such 'instant drop - slow recovery - concerted decay' type of behaviour was observed in the PDP traces throughout the entire probe spectrum, albeit with different relative efficiencies. There are two possible explanations for such recovery. First, the dump pulse may act as a repump as well, transferring a fraction of the excited population to higher electronic levels, which subsequently relax back to $S_{1}$. This would require ESA to be overlapping the SE band at the dump wavelength. Alternatively, the population of the dumped state may be replenished from the co-existing state within the excited state manifold, which is unaffected by the dump. The first explanation is unlikely due to long recovery times, which are of the order of several picoseconds, i.e. much longer than typical relaxation times of higher electronic states. Furthermore, no instant emergence of additional IA was detected after the dump, suggesting that no higher electronic states with characteristic absorption spectra were created. Therefore, the replenishment of the emissive state must be a result of the re-equilibration of populations between two states, one of which is dump-insensitive (perhaps, non-emissive).

The largest signal recovery was observed in the SE band, while it was somewhat less pronounced in the regions of ESA and photoisomer IA. In the region of the 'clean' GSB signal $(530 \mathrm{~nm})$ it was absent. Overall, dump induces a net loss of the photoisomer population (see traces at 530 and $570 \mathrm{~nm}$ in Fig. 3, where the signals at long delays are clearly diminished by the dump; also compare the red spectra in Fig. 2(a)). A decrease by approximately one third is clearly visible as a nearly constant induced absorption offset, extending beyond the nanosecond timescale.

Quite different trends are seen in the PDP results of SM1, depicted in Figs. 4 and 5. This short-lived dye was dumped at 1 ps after the excitation. More than one third of PP signal amplitude was lost in the region of 'clean' $S_{1}$ ESA (see trace at $420 \mathrm{~nm}$ ), while the SE band was diminished almost completely (Fig. $4(\mathrm{~d})$ ), where the negative signal was reduced to almost zero following the dump pulse (also compare the PP and PDP spectra in Fig. 5). At the same time, in the region of photoisomer absorption (trace at $590 \mathrm{~nm}$ ), a negative SE signal disappeared and was quickly replaced by a positive IA signal. No clear signs of the recovery of PDP traces are visible. When comparing PDP and PP traces in the region of isomer absorption, one can notice that a positive signal emerges earlier in the dumped data, but it starts to decay and never surpasses the maximum amplitude of PP traces. Therefore, there is no direct indication whether the dump pulse produces isomers in the ground state: the dump-induced emergence of a positive signal in the region of isomer absorption might as well originate from the decrease of SE. In the region dominated by GSB (trace at $560 \mathrm{~nm}$ ), the response to the dump was relatively smaller than that detected in the ESA/SE regions and virtually no net loss was observed at later times, as PDP and $\mathrm{PP}$ traces almost match at times $>10 \mathrm{ps}$. It is also apparent that the GSB signal takes a significantly longer time to decay than either ESA or SE, indicating the formation of longer-lived ground state species (tentatively ascribed to photoisomer).

It is also interesting to note that in SM1 the dumping effect is most pronounced immediately after the dump: the difference between PP and PDP traces vanishes at around 8 ps delay, whereas the overall signal is still clearly discernible at $20 \mathrm{ps}$. The immediate effect of the dump is further illustrated in Fig. 5, where the PP and PDP signals at $1.2 \mathrm{ps}$ are plotted. The difference between the two spectra is represented by a filledin blue curve. It is striking that the spectrum lost upon dumping accounts for all the SE signal and has its negative peak at $575 \mathrm{~nm}$, significantly shifted to the red with respect to the undumped PP spectrum. The remaining signal after the dump has no SE, and peaks at $570 \mathrm{~nm}$, the maximum of the ground state absorption. This clearly shows that the transient absorption spectrum observed at 1 ps delay consists of two excited state species, one emissive and one dark. Also, since this difference disappears at later times, it can be inferred that these two states are in equilibrium with each other, as was the case for the BF4 molecule. 

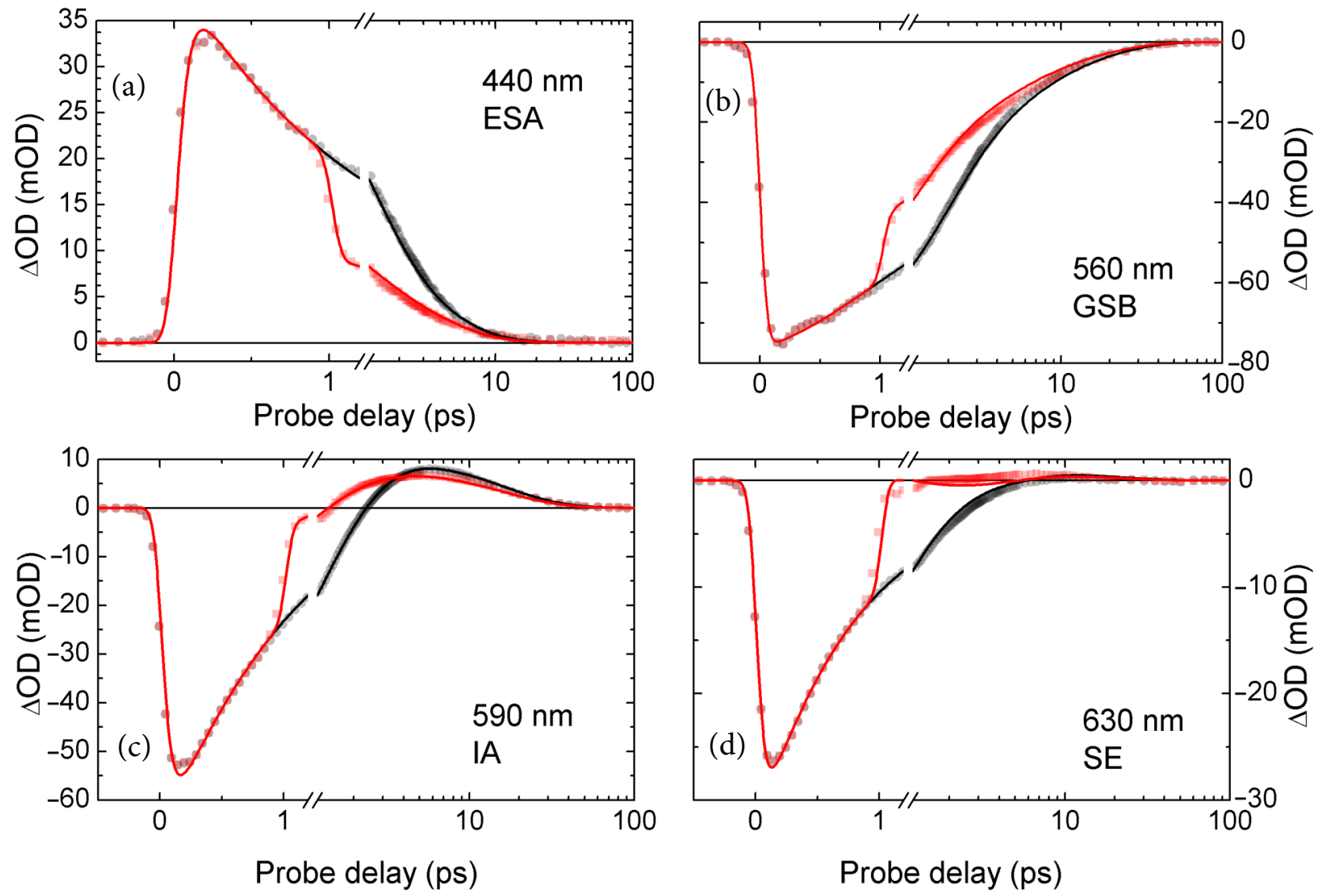

Fig. 4. PDP kinetics of SM1: PP (black circles) and PDP (red (online) squares) traces measured at different probe wavelengths with major contributions from ESA (a), GSB (b), IA of photoisomer (c) and SE (d) bands. Solid lines correspond to the global fitting results employing the connectivity scheme, shown in Fig. 6 . The dumping time was 1 ps.

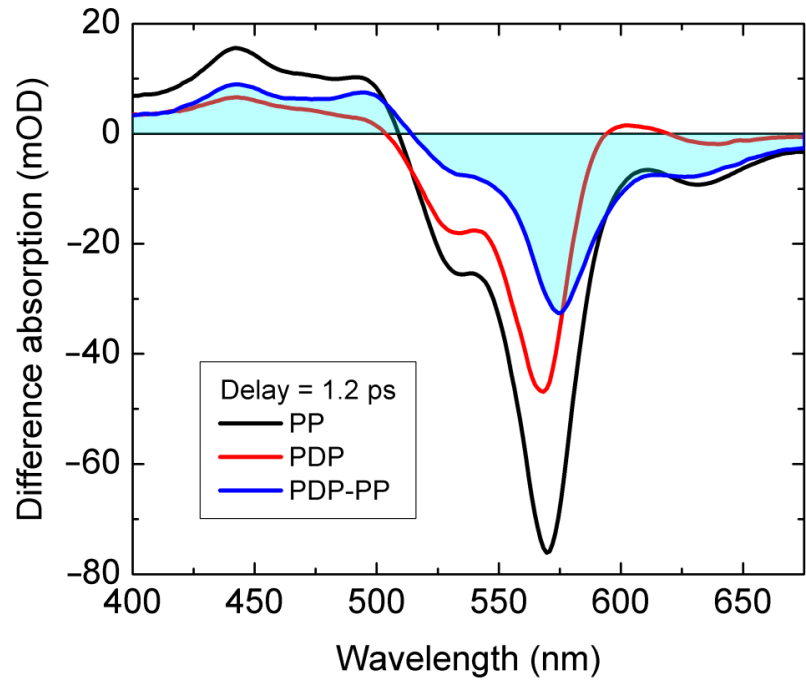

Fig. 5. Pump-dump probe data measured on SM1 immediately after the arrival of the dump pulse (1.2 ps delay, dump arrives at $1 \mathrm{ps}$ ). A black line shows the pump-probe signal in the absence of dump, a red (online) line shows the same signal when dump is present. The difference spectrum represents the signal that is lost immediately on dumping.

\section{Discussion}

The PDP results suggest that the excited state of both compounds must contain two states (emissive and non-emissive) in the dynamic equilibrium. In $\mathrm{BF} 4$, the existence of this state is obvious because the SE signal recovers after the dump when the equilibrium is re-established. This reequilibration is a direct evidence for a) the existence of two states, one of which is depleted by the dump, and the other is the reservoir to replenish its population, and $b$ ) the fact that their SE cross-sections are different because dump disrupts the equilibrium. In SM1, the excited state decay is so fast that re-equilibration is not observed clearly (which will be the case if the equilibration is slower than the excited state decay). However, the fact that dump produces a non-uniform effect on the spectra in Fig. 5 shows that the transient spectrum is comprised of coexisting species, only one of which is emissive. Note that there is no doubt that the dark state is an excited state: the shape of 
its ESA part of the spectrum is virtually identical to that of the dumped (emissive) state. It would be a striking coincidence if the unrelaxed ground state had exactly the same IA signature as the excited state. The amount of photoisomer absorption is affected by the dump in both cases (see Fig. 2); however, from this observation alone, it is impossible to say whether the isomer is formed via the emissive or non-emissive excited state. The two states are in equilibrium, and the perturbing one will inevitably have an effect on the later population of the other. The hint as to which pathway is operative is provided by the dumping of SM1, where the dump depletes the emissive state almost entirely. In spite of such large dumping effect, the resulting maximum IA of the isomer changed only slightly. If the isomer were produced via the emissive state, the only way to ensure its near constant yield in the dumped and the undumped scenario would be to have a very fast re-equilibration that would return all the population to the emissive state before the isomer is produced. This should result in the near-instantaneous recovery of the SE band, which is not observed in the data. In addition, since the photoisomer is a cis form of the compound, one would expect that the precursor that leads to the isomer would have an initial partly twisted conformation, and hence a broken conjugated system and no emission.

Based on these considerations, we adapt the model in Fig. 6 as a basis for the target analysis of PP and PDP data. The pump pulse puts the molecules in the Franck-Condon excited state (FC) that branches into two excited state intermediates (ESI1 and ESI2), representing the emissive and non-emissive excited states that are in equilibrium with each other (a dashed green arrow in Fig. 6). The non-emissive state ESI2 subsequently relaxes non-radiatively to produce the photoisomer. The emissive state ESI1 relaxes to the ground state either spontaneously, or via the SE induced by the dump pulse. The produced photoisomer relaxes back to the original ground state via thermal activation.

While this model captures all the essential processes occurring in the samples after the excitation, it had to be modified to provide an adequate description of the kinetic data. Namely, in the case of $\mathrm{BF} 4$, the relaxation of ESI2 was modified to proceed in two kinetic steps, whereas in SM1, the same had to be done to the photoisomer state.

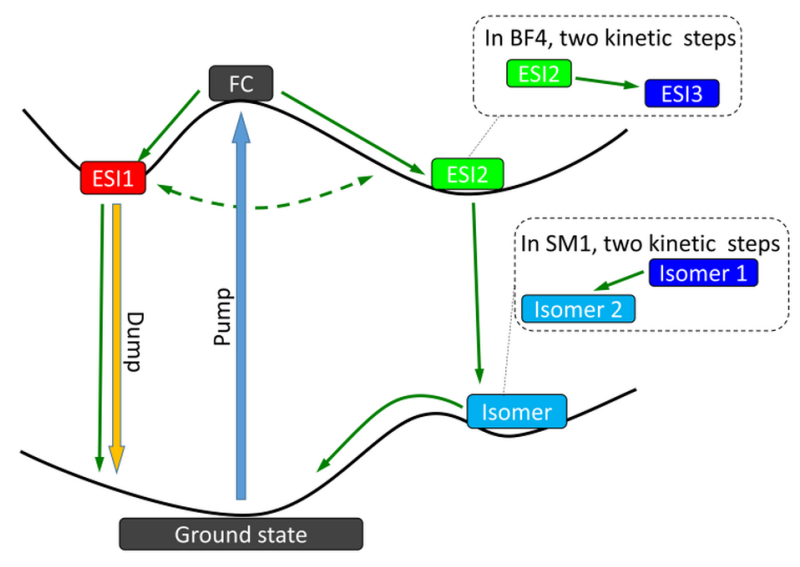

Fig. 6. The kinetic model used to fit the pump-dumpprobe data on SM1 and BF4. To produce an adequate description of the data, ESI2 was replaced with two kinetic steps in BF4 and the isomer relaxation was approximated by two kinetic steps in SM1 (shown in the insets). The actions of pump and dump pulses are shown by thick blue and orange (online) arrows, whereas kinetic steps are depicted by green (online) arrows. A double-ended dashed green (online) arrow shows the equilibrium perturbed by the dump pulse.

This can be expected because our model assumed linear kinetics, whereas the relaxation processes in question proceed together with solvation and intramolecular vibrational relaxation that are expected to produce continuously shifting spectra. Therefore, additional intermediate states representing such shifts as discrete transitions were required in order to adequately describe the experimental data. The reason why it was necessary in the ground state of SM1 and in the excited state of $\mathrm{BF} 4$ was probably the longer excited state lifetime of the latter. Since this allowed observing the excited state for a longer time span, more details were revealed by the data and had to be accounted for in the fitting.

Species-associated difference spectra (SADS), resulting from the global fit of PDP data, are presented in Fig. 7. The time constants representing the processes depicted by green arrows in Fig. 6 are presented in Table 1 . Since the SADS of the FC state was contaminated by a coherent coupling artefact, it is omitted from Fig. 7. As expected, the spectra of ESIs show the features of ESA, GSB and SE, whereas the isomer states are comprised of the bleaching bands and induced absorption slightly red-shifted with respect to their main absorption band. In SM1, the ESI2 shows virtually no 

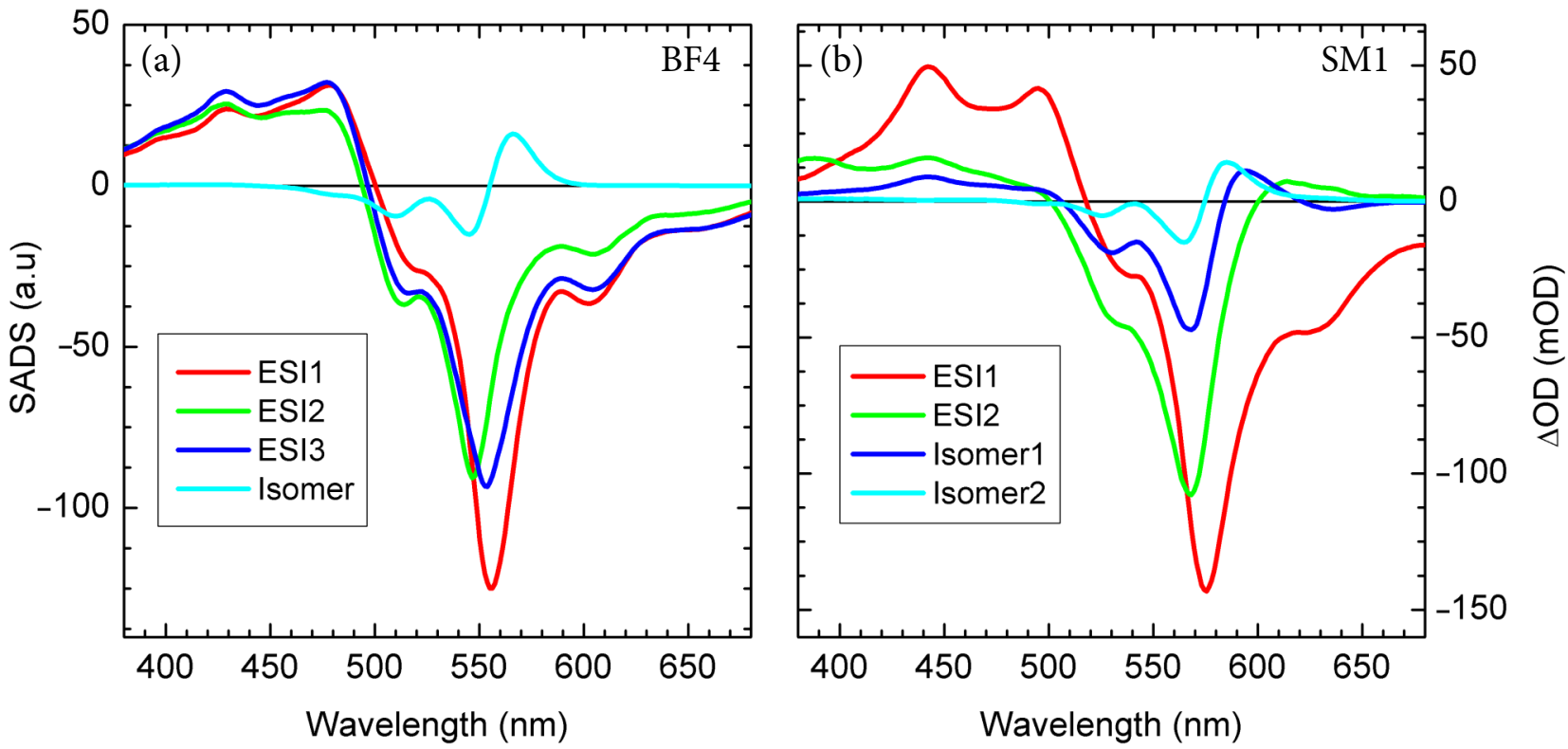

Fig. 7. Species-associated difference spectra resulting from the global analysis of PDP data on SM1 and BF4 using the model depicted in Fig. 6. The spectrum of the Franck-Condon state (FC) was obscured by a coherent coupling artefact and is omitted from the graphs. The estimated time constants representing different transitions are presented in Table 1, and the quality of the fit can be evaluated from Figs. 3 and 4.

$\mathrm{SE}$, whereas in BF4 emission is ca. two times lower than that of ESI1. In both cases, the negative peak of ESI2 is blue-shifted compared to that of ESI1. While it could represent different energies of these excited states, it is most probably the missing emission contribution that makes this band peak closer to the steady state absorption maximum. In both cases, the major channel of ESI1 relaxation turned out to be the transfer to ESI2 and subsequent isomer formation. Although the fitting of time-resolved data did not allow determining the natural decay time of ESI1 in SM1 (indicated as infinity in Table 1), the fact that steady-state fluorescence could be observed means that this decay channel is not completely blocked, just much less probable than the ESI $1 \rightarrow \mathrm{ESI} 2$ transition.

In the case of $\mathrm{BF} 4$, the excited state relaxation ESI2 $\rightarrow$ ESI3 results in a slight blue shift of the negative peak and the recovery of the SE signal. The lifetime of this spectral change is comparable with the solvation time in acetone [49]. The solvent can stabilize the excited state in a particular

Table 1. Estimated time constants (inverse transfer rates) connecting different compartments of the kinetic model shown in Fig. 6. The error bars on the rates were approximately $10 \%$ of their determined values. Infinite values mean that the inclusion of the corresponding transition in the model did not improve the quality of the fit.

\begin{tabular}{c|c|c|c|c|c}
\hline \multicolumn{2}{c}{ BF4 } & \multicolumn{2}{c}{ SM1 } \\
\hline From & To & Time const., ps & From & To & Time const., ps \\
\hline FC & ESI1 & 0.28 & FC & ESI1 & 0.07 \\
\hline FC & ESI2 & 0.41 & FC & ESI2 & 0.14 \\
\hline ESI1 & Ground state & 64 & ESI1 & Ground state & $\infty$ \\
\hline ESI2 & ESI3 & 13 & ESI2 & Isomer1 & 0.9 \\
\hline ESI3 & Isomer & 104 & Isomer1 & Isomer2 & 3.5 \\
\hline ESI1 & ESI2 & 10.2 & ESI1 & ESI2 & 0.94 \\
\hline ESI2 & ESI1 & 10 & ESI2 & ESI1 & $\infty$ \\
\hline Isomer & Ground state & $\infty$ & Isomer2 & Ground state & 12
\end{tabular}


confirmation with a higher conjugation length, resulting in the recovery of emission strength and the red shift of its maximum. At the same time, the ground-state relaxation of the photoisomer in SM1 (Isomer $1 \rightarrow$ Isomer2) is mainly a blue shift of the IA band and a concomitant decay of GSB. Such dynamics can be caused by any process that causes the gradual decrease of the ground state energy, the main candidates with a compatible time scale being ground state solvation, vibrational cooling and back-isomerization of the compound.

Although the model allows us to interpret the observed photoisomerization dynamics of two polymethine dyes in a single framework, it treats the observed rates as free parameters. The obvious question to address is the vast difference in the lifetimes of two compounds in the context of their structure. Since SM1 has additional covalent bonds that lock the structure of the polymethine bridge, a natural expectation would be that this would provide structural rigidity, and result in a longer excited state lifetime and a lower isomerization yield. The data shows precisely the opposite. Apparently, these additional bonds on an already short polymethine bridge create steric hindrances that distort the molecular structure in the ground state [41] and channel the excitation energy towards the remaining unlocked bond thereby promoting both isomerization and excited state decay.

\section{Conclusions}

We have applied pump-dump-probe spectroscopy as a tool to investigate the excited state dynamics in a pair of photoisomer-forming polymethine dyes with short conjugated chains. The first compound, BF4, has a high photoisomerization yield and a long ( $>10 \mathrm{~ns}$ ) lifetime of the photoisomers. The second compound, SM1, exhibits a very short excited state lifetime. In both compounds, the general picture of observed dynamics was the same and involved two coexisting excited states in the dynamic equilibrium. One of these states was emissive, while the other was dark. The dark state turned out to be a precursor of photoisomers observed via their characteristic induced absorption bands. Since the PDP experiments have shown that the two excited states can interconvert to one another, we conclude that the isomerization can proceed from a single excited state and hence - a single ground state. The target analysis of pump-dump-probe data allowed determining the characteristic lifetimes of population transfer between these states and building a comprehensive picture of photoinduced dynamics in the investigated compounds that may be applicable to other molecules of this class.

\section{Acknowledgements}

This research is funded by the European Regional Development Fund according to the supported activity 'Research Projects Implemented by World-class Researcher Groups' under Measure No. 01.2.2-LMT-K-718, Grant No. 01.2.2-LMTK-718-01-0014.

\section{References}

[1] A. Mishra, R.K. Behera, P.K. Behera, B.K. Mishra, and G.B. Behera, Cyanines during the 1990s: A review, Chem. Rev. 100, 1973-2012 (2000).

[2] V. Shirinian and A. Shimkin, in: Heterocyclic Polymethine Dyes, ed. L. Strekowski (Springer Berlin Heidelberg, 2008) pp. 75-105.

[3] M.Y. Berezin and S. Achilefu, Fluorescence lifetime measurements and biological imaging, Chem. Rev. 110, 2641-2684 (2010).

[4] H. Kobayashi, M. Ogawa, R. Alford, P.L. Choyke, and Y. Urano, New strategies for fluorescent probe design in medical diagnostic imaging, Chem. Rev. 110, 2620-2640 (2010).

[5] A. Hawe, M. Sutter, and W. Jiskoot, Extrinsic fluorescent dyes as tools for protein characterization, Pharm. Res. 25, 1487-1499 (2008).

[6] Z. Guo, S. Park, J. Yoon, and I. Shin, Recent progress in the development of near-infrared fluorescent probes for bioimaging applications, Chem. Soc. Rev. 43, 16-29 (2014).

[7] A.S. Tatikolov, Polymethine dyes as spectralfluorescent probes for biomacromolecules, J. Photochem. Photobiol. C 13, 55-90 (2012).

[8] S. van de Linde, S. Aufmkolk, C. Franke, T. Holm, T. Klein, A. Löschberger, S. Proppert, S. Wolter, and M. Sauer, Investigating cellular structures at the nanoscale with organic fluorophores, Chem. Biol. 20, 8-18 (2013). 
[9] M. Ptaszek, in: Progress in Molecular Biology and Translational Science, ed. C.M. May (Academic Press, 2013) pp. 59-108.

[10]J. Han and K. Burgess, Fluorescent indicators for intracellular $\mathrm{pH}$, Chem. Rev. 110, 2709-2728 (2010).

[11]M.S.T. Gonçalves, Fluorescent labeling of biomolecules with organic probes, Chem. Rev. 109, 190-212 (2009).

[12]S. Yao and K.D. Belfield, Two-photon fluorescent probes for bioimaging, Eur. J. Org. Chem. 2012, 3199-3217 (2012).

[13]R.M. Clegg, in: Laboratory Techniques in Biochemistry and Molecular Biology, ed. T.W.J. Gadella (Elsevier, 2009) pp. 1-57.

[14]R.M. Clegg, Fluorescence resonance energy transfer, Curr. Opin. Biotechnol. 6, 103-110 (1995).

[15]H. Wallrabe and A. Periasamy, Imaging protein molecules using FRET and FLIM microscopy, Curr. Opin. Biotechnol. 16, 19-27 (2005).

[16]J.A. Levitt, D.R. Matthews, S.M. Ameer-Beg, and K. Suhling, Fluorescence lifetime and polarization-resolved imaging in cell biology, Curr. Opin. Biotechnol. A 20, 28-36 (2009).

[17]R.M. Clegg, O. Holub, and C. Gohlke, in: Methods in Enzymology, ed. I.P. Gerard Marriott (Academic Press, 2003) pp. 509-542.

[18]J.L. Bricks, A.D. Kachkovskii, Y.L. Slominskii, A.O. Gerasov, and S.V. Popov, Molecular design of near infrared polymethine dyes: A review, Dyes Pigments 121, 238-255 (2015).

[19]S. Karaca and N. Elmac1, A computational study on the excited state properties of a cationic cyanine dye: TTBC, Comput. Theor. Chem. 964, 160-168 (2011).

[20]V.V. Egorov, Optical line shapes for polymethine dyes and their aggregates: Novel theory of quantum transitions and its correlation with experiment, J. Lumin. 131, 543-547 (2011).

[21]E.E. Jelley, Molecular, nematic and crystal states of 1,1'-diethyl- $\psi$-cyanine chloride, Nature 139, 631-631 (1937).

[22]G. Scheibe, L. Kandler, and H. Ecker, Polymerisation und polymere Adsorption als Ursache neuartiger Absorptionsbanden von organischen
Farbstoffen, Naturwissenschaften 25, 75-75 (1937).

[23]L. Zechmeister and J.H. Pinckard, On stereoisomerism in the cyanine dye series, Experientia 9, 16-17 (1953).

[24]C.J. Tredwell and C.M. Keary, Picosecond time resolved fluorescence lifetimes of the polymethine and related dyes, Chem. Phys. 43, 307-316 (1979).

[25]D.N. Dempster, T. Morrow, R. Rankin, and G.F. Thompson, Photochemical characteristics of cyanine dyes. Part 1.-3,3'-diethyloxadicarbocyanine iodide and 3,3'-diethylthiadicarbocyanine iodide, J. Chem. Soc. Faraday Trans. 68, 14791496 (1972).

[26]J.T. Knudtson and E.M. Eyring, Photophysical effects of stereoisomers in thiacarbocyanine dyes, J. Phys. Chem. 78, 2355-2363 (1974).

[27]D. Fassler and K.H. Feller, Picosecond spectroscopy of polymethine dyes, J. Mol. Struct. 173, 377-387 (1988).

[28]S. Abrash, S. Repinec, and R.M. Hochstrasser, The viscosity dependence and reaction coordinate for isomerization of cis-stilbene, J. Chem. Phys. 93, 1041-1053 (1990).

[29]F.E. Doany, R.M. Hochstrasser, B.I. Greene, and R.R. Millard, Femtosecond-resolved groundstate recovery of cis-stilbene in solution, Chem. Phys. Lett. 118, 1-5 (1985).

[30]H. Okamoto, Picosecond infrared spectroscopy of electronically excited trans-stilbene in solution in the fingerprint region, J. Phys. Chem. A 103, 5852-5857 (1999).

[31]R.J. Sension, S.T. Repinec, A.Z. Szarka, and R.M. Hochstrasser, Femtosecond laser studies of the cis-stilbene photoisomerization reactions, J. Chem. Phys. 98, 6291-6315 (1993).

[32]M. Lee, J.N. Haseltine, A.B. Smith, and R.M. Hochstrasser, Isomerization processes of electronically excited stilbene and diphenylbutadiene in liquids. Are they one-dimensional? J. Am. Chem. Soc. 111, 5044-5051 (1989).

[33]C. Burda, M.H. Abdel-Kader, S.Link, and M.A.ElSayed, Femtosecond dynamics of a simple merocyanine dye: Does deprotonation compete 
with isomerization? J. Am. Chem. Soc. 122, 6720-6726 (2000).

[34]G. Orlandi and W. Siebrand, Model for the direct photo-isomerization of stilbene, Chem. Phys. Lett. 30, 352-354 (1975).

[35]G. Ponterini and F. Momicchioli, Trans-cis photoisomerization mechanism of carbocyanines: experimental check of theoretical models, Chem. Phys. 151, 111-126 (1991).

[36]S.K. Rentsch, Modeling of the fast photoisomerisation process in polymethine dyes, Chem. Phys. 69, 81-87 (1982).

[37]F. Dietz and S.K. Rentsch, On the mechanism of photoisomerization and the structure of the photoisomers of cyanine dyes, Chem. Phys. 96, 145151 (1985).

[38]K.-H. Feller, R. Gadonas, and V. Krasauskas, Picosecond absorption spectroscopy of polymethine cis-trans isomerization, Laser Chem. 8, 39-47 (1988).

[39]M. Arvis and J.-C. Mialocq, Flash photolysis of cyanine dyes. Pinacyanol chloride (1,1'-diethyl2,2'-carbocyanine chloride), J. Chem. Soc. Faraday Trans. 75, 415-421 (1979).

[40]H. Görner, Photoprocesses in spiropyrans and their merocyanine isomers: Effects of temperature and viscosity, Chem. Phys. 222, 315-329 (1997).

[41]V. Voiciuk, K. Redeckas, N.A. Derevyanko, A.V. Kulinich, M. Barkauskas, M. Vengris, V. Sirutkaitis, and A.A. Ishchenko, Study of photophysical properties of a series of polymethine dyes by femtosecond laser photolysis, Dyes Pigments 109, 120-126 (2014).

[42]D.S. Larsen, E. Papagiannakis, I.H.M. van Stokkum, M. Vengris, J.T.M. Kennis, and R. van Grondelle, Excited state dynamics of beta-caro- tene explored with dispersed multi-pulse transient absorption, Chem. Phys. Lett. 381, 733-742 (2003).

[43]J.T.M. Kennis, D.S. Larsen, N.H.M. van Stokkum, M. Vengris, J.J. van Thor, and R. van Grondelle, Uncovering the hidden ground state of green fluorescent protein, Proc. Natl. Acad. Sci. U.S.A. 101, 17988-17993 (2004).

[44]D.S. Larsen, I.H.M. van Stokkum, M. Vengris, M.A.van der Horst,F.L. de Weerd,K.J.Hellingwerf, and R. van Grondelle, Incoherent manipulation of the photoactive yellow protein photocycle with dispersed pump-dump-probe spectroscopy, Biophys. J. 87, 1858-1872 (2004).

[45]D.S. Larsen, M. Vengris, I.H.M. van Stokkum, M.A. van der Horst, F.L. de Weerd, K.J. Hellingwerf, and R. van Grondelle, Photoisomerization and photoionization of the photoactive yellow protein chromophore in solution, Biophys. J. 86, 2538-2550 (2004).

[46]A.A. Ishchenko, The length of the polymethine chain and the spectral-luminescent properties of symmetrical cyanine dyes, Russ. Chem. Bull. 43, 1161-1174 (1994).

[47]A.V. Kulinich, N.A. Derevyanko, and A.A. Ishchenko, Synthesis and spectral properties of cyanine dyes - Derivatives of 10,10-dimethyl7,8,9,10-tetrahydro-6H-pyrido[1,2-a]indolium, J. Photochem. Photobiol. A 198, 119-125 (2008).

[48]K. Redeckas, V. Voiciuk, R. Steponavičiūtè, V. Martynaitis, A. Šačkus, and M. Vengris, Optically controlled molecular switching of an indolobenzoxazine-type photochromic compound, J. Phys. Chem. A 118, 5642-5651 (2014).

[49] M. Maroncelli, The dynamics of solvation in polar liquids, J. Mol. Liq. 57, 1-37 (1993). 


\title{
TAMSIỤJŲ BŪSENUU POLIMETININIUOSE DAŽIKLIUOSE ATSKLEIDIMAS, PANAUDOJANT ŻADINIMO-EMISIJOS STIMULIAVIMO-ZONDAVIMO SPEKTROSKOPIJĄ
}

\author{
K. Redeckas ${ }^{\text {a }}$, V. Voiciuk ${ }^{a}$, A.A. Ishchenko ${ }^{b}$, M. Vengris ${ }^{a}$ \\ ${ }^{a}$ Vilniaus universiteto Fizikos fakulteto Lazeriniu tyrimu centras, Vilnius, Lietuva \\ ${ }^{\mathrm{b}}$ Ukrainos nacionalines mokslu akademijos Organines chemijos institutas, Kijevas, Ukraina
}

\section{Santrauka}

Darbe tirta dviejų simetrinių polimetininių dažiklių fotoizomerizacija trijų impulsų kinetinès sugerties spektroskopijos metodu. Žadinimo-emisijos stimuliavimozondavimo eksperimentai parodè, kad šių molekulių žemiausių sužadintų būsenų sistemą sudaro dvi energetiškai artimos sužadintos būsenos, tarp kurių yra dinaminė pusiausvyra. Viena iš šių būsenų pasižymi emisija, o kita - beveik ne. Tamsioji būsena yra molekulès fotoizomero prekursorius, ir būtent jos metu šiose molekulèse relaksuoja didžioji dalis sužadintų būsenų. Taip pat paro-
\end{abstract}

dyta, kad tarp šių būsenų egzistuoja dinaminè pusiausvyra, o tai reiškia, kad fotoizomerizacijos vyksmo iš anksto nelemia molekulès geometrinė konfigūracija pagrindinèje būsenoje. Molekulè „apsisprendžia“, ar jai izomerizuotis, ar ne jau sužadintoje būsenoje. Panaudojant globaliąją trijų impulsų kinetinès spektroskopijos duomenų analizę, buvo nustatyti tarpinių fotoreakcijos produktų spektrai pagrindinèje ir sužadintoje būsenose bei sukurtas detalus fotoindukuotos dinamikos simetriniuose polimetininiuose dažikliuose modelis. 